\title{
PROFILE: SUSANNA EASTBURN
}

Susanna Eastburn took up the role of Chief Executive of Sound and Music in September 2012. This is the latest senior appointment in a varied career that has included being Director, Music at Arts Council England from 20082012 and Executive Director of LIFT London International Festival of Theatre between 2005 and 2008. Her background and particular interest is in new music and in supporting composers at different times in their career. Her first job was in music publishing,

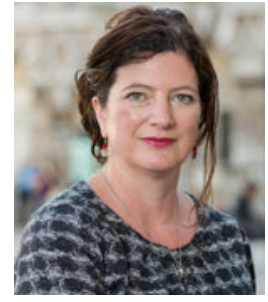

Susanna Eastburn [photo credit Sound and Music] working as International Promotions Manager at Music Sales Ltd with a number of leading composers including Judith Weir, Kaija Saariaho and Esa-Pekka Salonen. At the age of 32 she was appointed as Artistic Director and Chief Executive of the Huddersfield Contemporary Music Festival, a role she fulfilled between 2000 and 2004, when she was selected to be a Youth Music Fellow on the inaugural year of the Clore Leadership Programme, an initiative to identify and develop leadership in the cultural sector. In September 2013 she was elected to be President of the International Association of Music Information Centres. She is on the Board of Birmingham Contemporary Music Group and is a Trustee of Trinity College London. She is a keen chamber musician and plays the viola.

Q. 'New', 'contemporary', 'modern': what attracts you to 'this' music? A. I am interested in things that say something to me about these strange times we live in. That's not to imply that 'classical' music can't do that, but I am attracted to music that doesn't sound like anything else, that has the capacity to amaze and transform my way of thinking. It's always what I'm hoping for when I go to a performance.

Q. What current developments or trends do you perceive in new music?

A. At Sound and Music we are working intensively with around 80 composers at any one time. Most but not all of them will be in the earlier part of their professional life as a composer. Based on what these composers tell us, I would highlight three trends in particular. Firstly, that this generation of composers (and indeed audiences) tends to be much more eclectic and pluralistic in their work and their listening, rather than fitting neatly into pre-established notions of genre. Secondly, that many composers are setting up and producing their own events. Perhaps this is an inevitable result of austerity and rapid diminishment of traditional models of commissioning and publishing, but I would say that it is at these composer-led events that I often hear the freshest new music, and witness the most interesting encounters between artists and audiences. Thirdly, that in a fully emerged digital age, the notion of a composer's public identity has become much more complicated and is no longer experienced solely through the work itself. 
Q. You've held some fascinating roles, at hcmf//, Arts Council England and now Sound and Music: what has driven this evolution of your career?

A. You make it sound like I had a plan; I can assure you that I didn't ... I think I have been lucky in the opportunities that have presented themselves; I have been able to take on roles that combined a clear sense of purpose with being incredibly stimulating and slightly terrifying. With Sound and Music, the organisation was facing a lot of external negativity when I started and was in the middle of an enormous restructure and downsizing. I felt so strongly that this kind of national, unifying organisation was essential in order to create a powerful engine to drive new music and advocate for it nationally, and it was a moment when I felt I had to step up to the plate and have a go at sorting it out. I guess I like a challenge as well.

Q. How would you describe your role, what it is that you do?

A. I spend a lot of time fundraising and thinking about how to raise the money we need in order to do what we need to do. That aside, my role entails a lot of listening - to music, of course, but also I am constantly absorbing and processing information in order to ensure that on limited resources we can achieve the greatest impact for composers and for new music audiences.

Q. What are you reading at the moment?

A. I am, with huge pleasure, working my way through the new Penguin translations of Georges Simenon's Inspector Maigret series.

Q. What is your perspective on the new music scene in the UK? A. The UK is one of the most exciting and vibrant places for new music in the world at the moment - the artistic curiosity, variety and inventiveness of the composers we have here is unparalleled. The greatest risk to new music in the UK is that the demographic from which composers emerge seems to be narrowing. We see evidence that at every transitional stage of development, composers are much more likely to give up if they are a woman, from a nonwhite ethnic background or disabled. I am also sure (although it is harder to measure) that this is true for composers from lower socioeconomic backgrounds. This is an artistic as well as a social justice issue. Who knows what potentially great talents are falling by the wayside?

Q. What's coming up for Sound and Music?

A. Lots of things - new residencies with an incredible mix of partners ranging from the BBC Symphony Orchestra, Kuljit Bhamra, the Lichfield Festival and the South London Gallery. This time of year (I'm writing this in June) for us also marks the lead up to our annual residential Summer School for composers aged 14-18, which happens in August with 75 young composers in residence for a week. We are also seeing Minute of Listening, our primary school software application for whole-class reflective listening, take off with our first music education hub partnership as well as international interest.

Q. Is the future bright for new music?

A. Of course it is. But it will look very different. 